\title{
The Influence of Information Commons on User Traffic Pattems and Perceptions of the Library
}

\author{
정보공유공간이 이용자 유동패턴과 도서관인식에 미치는 영향 \\ Ji-Hong Park (박지홍)* \\ Jinhee Park (박진희)** \\ Eunkyung Nam (남은경)*** \\ Seoha Lee (이서하)****
}

\begin{abstract}
During the last decade, increasing use of technology that facilitates information access has changed academic library services. The emergence of information commons is one of the key changes. Most previous studies on information commons have focused on its conception and role. Whereas, considering information commons as a spatial service, this study aims to examine the influence of information commons on user traffic patterns within the library and perception of the library. As the information commons grew into main library service space and facility, it is necessary to explore what influences information commons have on the behavior and recognition of users. Two methods were used. First, observation method was used to record traffic pattern and user behavior. Second, twenty undergraduates and twelve graduates were interviewed regarding the use and recognition of the information commons and the library. The results of the study show that the traffic patterns were different between undergraduate students and graduate students; the location and structure of facilities influences their movement and behaviors; and the recognition of information commons tends to affect the perception of the entire library. The findings may help librarians improve and plan for library spaces to meet user demands.
\end{abstract}

\section{초 록}

정보에 대한 접근을 증가시키는 기술의 사용은 지난 십 년 동안 대학도서관 서비스에 많은 변화를 가져왔다. 정보공유공 간의 등장은 이러한 변화 중 하나이다. 이에 대한 대부분의 이전 연구는 이의 개념이나 역할에 치중하였다. 반면, 정보공유공 간을 공간서비스로 파악하고 있는 본 연구의 목적은 정보공유공간이 이용자 유동패턴과 도서관인식에 어떤 영향을 미치는지 파악하는데 있다. 정보공유공간이 도서관의 주요 공간과 시설로 자리매김하였고 이에 따라 이들이 이용자의 행위와 인식에 어떤 영향을 미치는지 알아볼 필요가 있다. 본 연구는 두 가지의 연구방법을 사용하였다. 첫째, 관찰법을 사용하여 이용자들의 유동 패턴 및 행위를 관찰하였고, 둘째, 정보공유공간에 대한 이용과 인식에 관한 인터뷰를 20 명의 학부학생과 12 명의 대학원생을 대상으로 수행하였다. 본 연구의 결과로서 학부학생과 대학원생은 서로 차별화 되는 유동패턴을 보였고, 시설의 위치와 구조는 이용자들의 움직임과 행위에 영향을 미쳤으며, 또한 정보공유공간에 대한 인식은 도서관 전반에 대한 인식으로 해석되는 경향을 보였다. 본 연구결과는 이용자 요구를 고려한 도서관 공간 설계 및 향상에 도움이 될 것이다.

Keywords: information commons, traffic patterns, library perception, observation 정보공유공간, 유동패턴, 도서관인식, 관찰법

* 연세대학교 문헌정보학과 부교수(jihongpark@yonsei.ac.kr) (교신저자)

**연세대학교 문헌정보학과 대학원 석사과정(jinihoho@yonsei.ac.kr)

*** 연세대학교 문헌정보학과 대학원 석사과정(namek@yonsei.ac.kr)

****연세대학교 문헌정보학과 대학원 석사과정(sallylee1216@yonsei.ac.kr)

- 논문접수일자 : 2013년 11월 13일 - 최초심사일자 : 2013년 12월 4일 - 게재확정일자 : 2013년 12월 10일

- 정보관리학회지, 30(4), 93-110, 2013. [http://dx.doi.org/10.3743/KOSIM.2013.30.4.093〕 


\section{Introduction}

The academic library is usually considered "the heart" of the university. It is no exaggeration to say that a university without a library could not even exist. One of fundamental roles of academic library services is to provide relevant information sources to the library users, including students, administrative staff, and scholars advancing their fields of inquiry. Yet, the library's role is no longer limited to furnishing data to its users. The evolution of the library has led to changes in its physical structure and the consequential transformation of its role. Libraries have tried to reflect the changes in the way they are used and resources they provide, shifting toward cooperative learning and group study. Such changes have resulted in information commons (IC). Since its opening, IC has increased its influence within the library due to the influence of the digital age. According to Lippincott and Oblinger (2006), "Information commons have drawn students by offering environments that address their needs, bringing together technology, content and services in a physical space that results in an environment different from that of a typical library" (p. 2). The IC also has increased library use by providing public space to collaborate inside the facility. One St. Thomas University librarian explained that the commons area actually attracts students and increases the gate count to $110 \%$ higher prior to the opening of the space (Lippincott \& Oblinger, 2006).

Because IC reflects a comparatively new transition in library environments, reliable research on this sub- ject is lacking. Furthermore, relatively few studies have focused on the influence of the physical environment of the library on user behavior and their perceptions of the library. Previous studies on the physical environments of libraries have examined uses of various library spaces, including IC and user satisfaction. Campbell and Shlechter (1979) analyzed the effect of external library design on user behavior and satisfaciton. Thereafter, libraries implemented innovative changes to its environment, including public spaces and IC. Halbert (2010) and Whitchurch (2010) focused on changes in library space with the emergence of the digital age. Although many studies investigated these changes, most did not interpret these changes in connection with users' perceptions; instead, most concentrated on user satisfaction.

In the present research, as the information commons grew into main library service space and facility, we aim to explore the influences of information commons on the behavior and the perceptions of users. It will provide an opportunity to recognize the space needs of users. Therefore, we investigate user behaviors in the IC and user perceptions of the library. The setting chosen was the IC and U-Lounge of Yonsei-Samsung library. Undergraduate and graduate students, the main academic library users, were selected as respondents. In the process of conducting this study, we first observed user behavior in different areas of the space in order to visualize user traffic patterns. We then interviewed these users to identify their changes in recognition of the library. Implications from these findings can lead to better understanding desirable roles of common spaces in 
a digital age. Moreover, describing the relationship between the IC and user perceptions can help librarians plan library spaces to meet user demands.

\section{Literature Review}

The emergence, role, and influence of the IC are typically the focus of prior studies. Among these studies, we examine the concepts, functions, and perceptions of IC to examine gaps in previous studies.

Previous studies focused on the IC being either technology-common space or knowledge-common space. Some described the IC as a facility for technological uses. For example, Beagle (1999) identified IC as online space providing various types of digital services. It refers to physical spaces devoted to using computers for information discovery and creation. MacWhinnie (2003) called IC the "tech labs" of the library. In contrast, other scholars consider IC as knowledge-common space. According to continued changes within academia, the IC has expanded and started to implement more learning-centered technologies and services. Beagle (1999) explained that the IC acts as a "physical facility designed to organize workspace and service delivery around the integrated digital environment" (p. 82). Lippincort and Oblinger (2006) configured its features to support “group spaces" and "personnel assistance with users' technology needs" (p. 73). In addition, there is a movement to expand the concept of the IC. Beagle (2010) portrayed IC as places to "host collaborative programs of learning support-like Writing Center and Tutoring and Learning Services" (p. 17). In the present article, we identify IC as a more inclusive concept, defining it as a collaborative learning space in a technology-enhanced environment rather than either technology or knowledge oriented.

The IC provides a leaning and socializing space. Lippincott and Oblinger (2006) clarified that the role of IC is to encourage user learning in combination with pervasive technology and integrated services in the context of their academic work. Many IC facilities are designed to support individual private study as well as collaborative group study (Bryant, Matthews, \& Walton, 2009). Some researchers have concluded that the IC functions as the socializing space. Lippincott (2010) understood that the IC is the physical space for socializing and learning in a social context as well as adapting to technical changes in the environment. Bryant, Matthews, and Walton (2009) stated that it is a popular gathering space for engaging in various social activities. Based on these definitions, we identify the IC as a knowledge commons, a place for creating knowledge, and sharing support by socializing and learning. Seal (2005) emphasized the role of the IC as knowledge creation space, mentioning that "The IC is a place where information is retrieved and used to create knowledge, where students become information literate and ultimately knowledge managers" (p. 74). Bennett (2003) thought that establishing the IC has different goals from the traditional library: the core activity of the IC is the collaborative learning by which students turn information into knowledge and sometimes into wisdom. 
There are differences in behaviors and perceptions on information sources between undergraduate students and graduate students. Barret (2005) perceived lecture notes, textbooks, and reserve materials as valued sources of information for undergraduates. Hartmann (2001) placed heavy emphasis on the use of journal articles, which came as a surprise to undergraduates, who had no experience in searching more varied forms of information sources. Unlike undergraduates, graduates have specific research needs for their major. They prefer journal articles, which provide them with authentic information and full-text content (Bae, 2010). As more information becomes available online, most graduate students tend to perform individual studies in their own labs rather than physically using the library. In contrast, undergraduates become primarily library users who aim to find monographs and journals (Hiller, 2002). In the present study, we pay attention to how the facilities and space of IC affect the user movements and their perceptions of the library.

The emergence of the IC has transformed users' perceptions of library. Thus, the importance of considering user satisfaction in the context of the digital environment is increasing (Cullen, 2001). Several recent case studies have examined the changes the IC has created, including increased usage rates, diversified users patterns of library use, and so on. At Westminster College, after the library opened an IC, higher gate counts were reported (Malenfant, 2006). Other studies have looked at users' purposes and behaviors in the IC (Beatty, 2010). More recently, Stoffle and Cullier (2010) at the University of Arizona found that the IC became one of the users' most preferred spaces in the library because of its facilities and services, which meet users' needs. Other related studies such as Given \& Leckie (2003) and Mandel (2010) stressed the importance of understanding library users' movement when they seek information. Mandel (2010) examines, by unobtrusive observation, wayfinding behaviors in public library setting and reports that most users use only a few entry routes mostly though there were more than 100 entry routes. Given \& Leckie (2003) introduces a spatial analysis technique that has a potential for library facilities design by considering their usage patterns and behaviors.

The majority of studies on IC spaces have explored the role of IC user satisfaction or preferences regarding the IC. Few studies have focused on how the IC affects behavior or perceptions from different user groups such as undergraduates and graduates. Thus, learning about the influence of the IC on users' perception of the entire library is valuable, as is looking at it as related to defining the roles of the library and organizing spaces in the digital age.

\section{Methods}

The setting chosen was the information commons (IC) and U-Lounge area at Yonsei-Samsung Library of Yonsei University in Seoul, Korea. We examined the IC and the U-Lounge together and conceptualize them as IC because we adopt the IC concept as a collaborative learning space in a technology-enhanced 
environment. While the space called 'information commons' at Yonsei only focus on technology-oriented space, it was necessary to include U-Loung space which is adjacent and looks same space as the IC space.

To explore how this space influences the perception of the library, two data-gathering methods were used: unobtrusive observation and semi-structured interviews. Three researchers performed the unobtrusive observations and then interviewed observed users those who agreed to share their opinions. The observers found it difficult to identify graduates by sight; therefore, we conducted additional interview of graduates at a later time. We selected the observation method to record both users' traffic patterns and their behavior in this specific area. Campbell and Shlechter (1976) stated this method would give information on the distribution of behavior in a given space and provide a representative description of how the area is used. Sommer and Sommer (1997) explained that an individual-centered map had the advantage of tracking the individual's movements over time and space. In addition to the observation methodology, we conducted interviews using semi-structured questions to examine users' experiences and perceptions of the library in terms of using the IC and U-Lounge spaces. We chose semi-structured interviews so that we not only narrow down the topic concerning changes in recognition but also allow interviewees to share different thoughts and feelings as we probed for information. Using semi-structured interviews, we could probe to understand the respondents' perspectives. Longhurst
(2003) stated the advantage of the semi-structured interview for investigating complex behaviors, opinions, and emotions for collecting a diversity of experiences.

The present research used the procedure outlined in the following sections. First, we began this research by reviewing previous studies to collect information about IC spaces. Then, data collection was conducted based on pilot data collection for one month. Data was analyzed to determine how information commons influences user behavior and perceptions of the library.

\subsection{Data Collection}

We conducted unobtrusive observations and interviews at the Yonsei-Samsung library's IC and U-Lounge. The observation was conducted every Monday from 3:00 pm to 5:30 pm in the middle of the semester. Semi-structured interviews were carried out after each observation session at various areas of library. Interviews lasted about 10 minutes and were recorded if the interviewees agreed.

There are two different types of samples. One is for the observations and the other is for the interviews. To observe users' traffic patterns and behavior in a given space, observers scanned people using the information commons and U-Lounge of Yonsei-Samsung Library. To minimize any bias from time differences, we observed users at the same time on the same days each week. For this observation, we randomly picked the samples entering the IC and U-Lounge in every $5^{\text {th }}$ order and staying there 
for more than 10 minutes. Observers followed each user and marked their location on the floor plan and mapped their behavior on the observation sheet. Every 30 minutes, each observer recorded activities of all users at each place. The total number of observed sample was 46 users consisted of 21 in IC and 25 in U-Lounge.

For the interviews, we gather information on attitudes toward the library based on the purposive sampling. The samples were selected in a deliberative fashion to obtain specific responses to inquiries. The purposive method helps look beyond random sampling designs (Tongco, 2007). We interviewed 32 library users who were leaving the IC or U-Lounge after spending more than ten minutes inside. Interviewees were limited to users whose traffic patterns were previously observed. The interview ques- tions were categorized into two user groups: frequent visitors and rare visitors. Frequent visitors were asked eleven questions and rare visitors were asked seven questions. Overall, we interviewed 20 undergraduates and 12 graduates.

The Yonsei-Samsung library's IC and U-Lounge were constructed in 2008 during the remodeling period of Yonsei Central Library. The IC provides spaces for Internet PCs, a writing/editing zone, digital library search area, laptop area, and collaboration booths (see Figure 1). The U-Lounge includes user-service centers, sofas, benches, u-tables, a global PC Island, e-book area, various touch-screen stands such as Intelliboard, Memoboard, and newsstands, which are available for reading news and magazines and finding locations and books at library (see Figure 2).

\begin{tabular}{|c|c|c|}
\hline \multicolumn{3}{|c|}{ Gate } \\
\hline Internet PCs & & Internet PCs \\
\hline Laptop Area & & Laptop Area \\
\hline Writing/Editing Zone & & Writing/Editing Zone \\
\hline Laptop Area & & Laptop Area \\
\hline Digital Library Search Area & & Digital Library Search Area \\
\hline Collaboration Booth & & Collaboration Booth \\
\hline User Education Room & Help Desk & \\
\hline Elevator & & Elevator \\
\hline
\end{tabular}

〈Figure 1〉 Floor plan of IC 


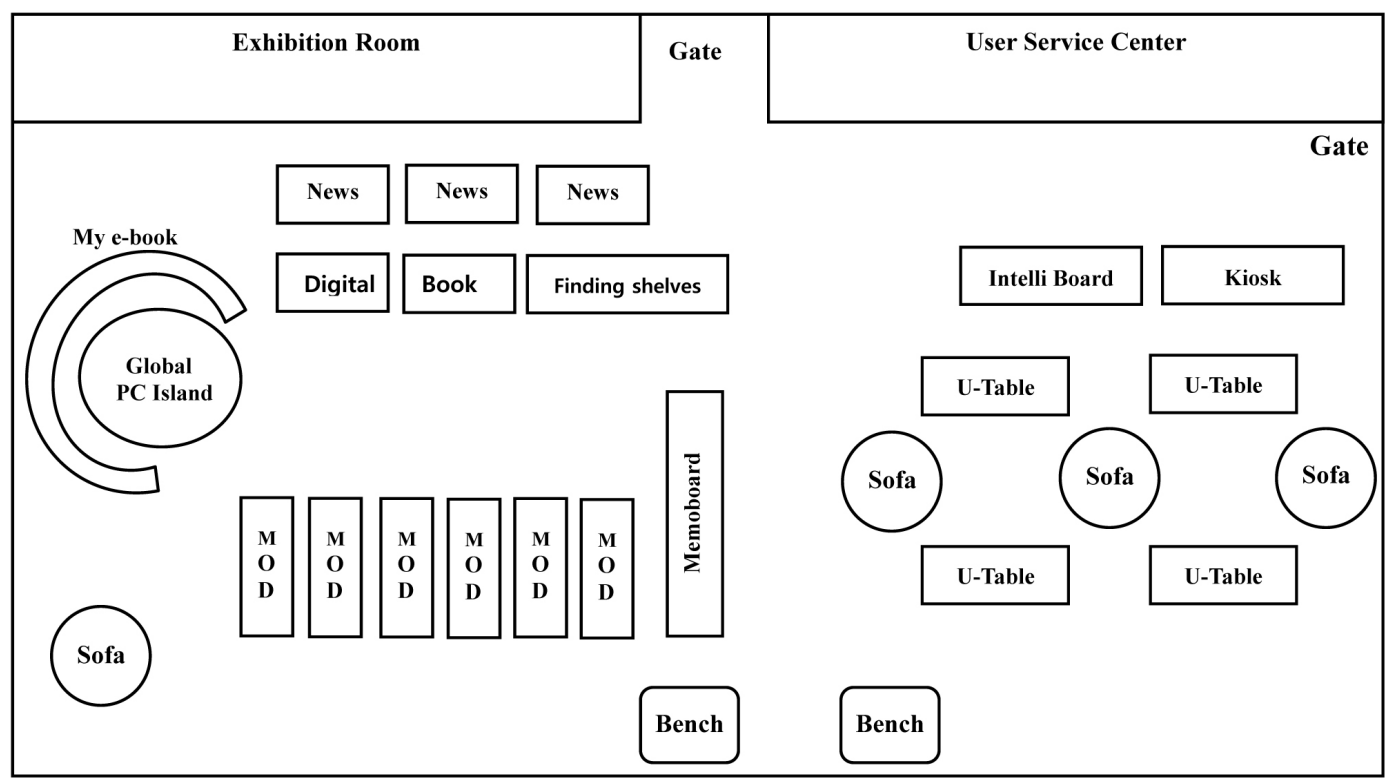

〈Figure 2〉 Floor plan of U-Lounge

\section{Unobtrusive Observation Data Analysis and Findings}

\subsection{Traffic Patterns}

Figures 3 and 4 illustrate the flow of user traffic in the information commons, for an instance. These figures are based on the integration of the five observation results. As mentioned before, it is quite an impractical to follow all the user traffics of the 4-month period, we randomly selected 46 users (21 in IC and 25 in U-Lounge). For Figure 3 and 4, the 21 users were not observed in a single moment but a combined set of 4-month-period data. The number in the figures shows the number of users in a spot, and the arrows are the movement path of users observed in every 30 minute, if the users move from one spot to others.
The results show quite a simple pattern. Overall, 17 out of 21 observed users remained in one specific space and the remainder moved to another section within the IC. Most users stayed in a certain area of the IC for an average of 63 minutes using computers on their own. This might be related to the circumstance that users can reserve seats up to maximum of two hours. When they reserve seats, they tend to recognize the IC as a "computer space" even though the IC classifies sections according to the originally designed purposes, as Figure 1 shows.

The primary difference between the undergraduate and graduate user groups was in terms of frequency of visits. Many undergraduates use the IC frequently, whereas few graduates do. Undergraduate interviewees reported visiting the library an average of three days a week to complete assignments, surf 
the Internet, and study in groups between classes. to study individually in a personal lab, for example, However, graduates seldom visit the IC as they prefer rather than collaboratively.

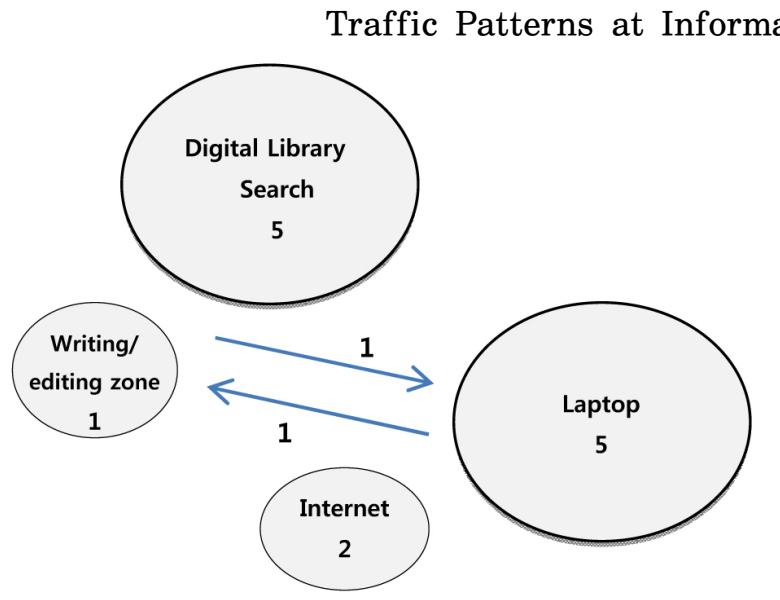

〈Figure 3〉 Undergraduates

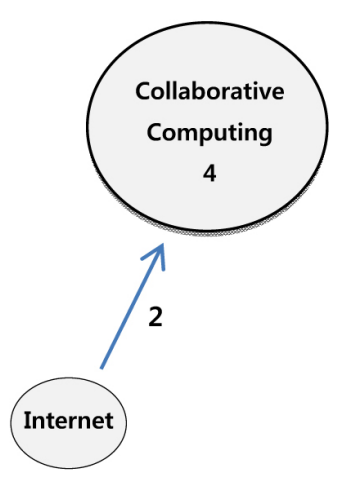

〈Figure 4〉 Graduates

Traffic Patterns at U-Lounge

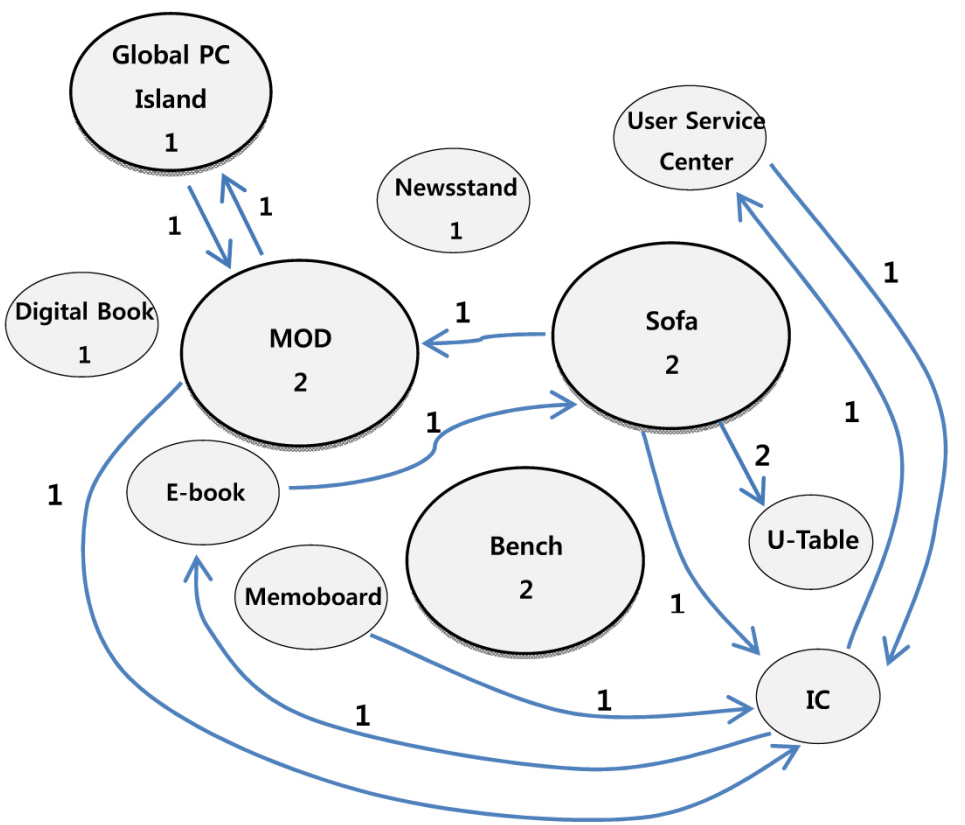

〈Figure 5〉 Undergraduates

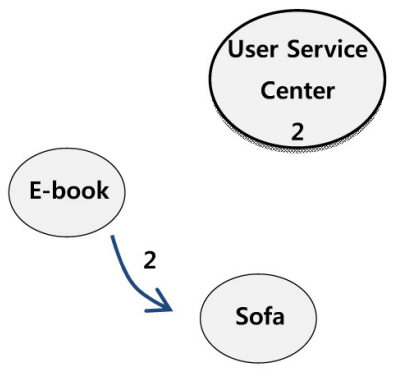

〈Figure 6〉 Graduates 
Figures 5 and 6 show the slightly more complex traffic pattern of users at the U-Lounge compared to the IC. Like in Figure 3 and 4, the number in the figures also shows the number of users within a spot. Overall, 14 of 25 observed people shifted their location and the remaining 11 stayed in one spot or left the U-lounge after staying in User Service Center and Newsstand spots. Location changes occurred frequently according to the user's purpose. For example, some people enjoyed taking a break from working collaboratively at a table and resting on the sofa. This was a unique feature of the U-Lounge, which combines academic places with resting spaces, unlike the IC. Many undergraduates showed remarkable attitudes toward using the library. They preferred a somewhat noisy environment to a quiet environment. Graduates, however, feel uncomfortable with the space because of the noise. If they visit, they follow a distinct pattern of traffic in that most of them leave the library as soon as they achieve their purpose, such as using the interlibrary loan service.

Many undergraduates using the IC tend to prefer seats with computers to any other space. When they use the U-Lounge, they like to rest on the sofas and benches. The degree of crowding shows that is the space they like and use most frequently. In the afternoon, when the observation and interviews were conducted, most of the computing-seats and spaces for resting such as sofas were crowed with students after or between their classes. In contrast, graduates, the infrequent visitors, show a unique pattern of using the space. They usually visit a user service center to use the interlibrary loan service, unlike the undergraduates.

\subsection{Behavioral Patterns}

Figures 7 and 8 illustrate the frequency of activities among users in the IC and the U-Lounge. There is quite an opposite pattern of user behavior in the two spaces because of their structural differences. People use both spaces mainly for personal studying but a few distinct aspects between two places were noticed.

Users in the IC tended to stay in one spot during their stay, whereas the flow of human traffic was dynamic at the U-Lounge. People in the U-Lounge engaged in more varied activities than they did in the IC, and it is usually crowded with many passers.

Most users in the IC carried out a computer-related task. It was found that $71.6 \%$ of students use computers in the IC engaged in diverse activities, such as doing assignments, searching for information, printing, and scanning. However, only $8.8 \%$ of students in the U-Lounge used computers. Others were involved in a variety of activities, such as resting, reading, socializing, personal studying, and collaboration. A total of $36.4 \%$ of users in the U-Lounge fell into the resting category, whereas only $1 \%$ took a rest in the IC.

Most users tended to do their own tasks individually in the IC using computers. This could be because the IC comprises mainly individual computers for digital searching or writing/editing. A total of $19.9 \%$ of the users worked collaboratively and talked casually. In contrast, more users were categorized into the collaboration category at the U-Lounge 
compared to the IC, even though the U-Lounge has no designated group workspace. In the U-Lounge, an easily accessible location within the library, many people have quick access to diverse facilities such as newsstands, a memo board, bench, and sofa. Most of the users stayed there for a moment, engaging in diverse social activities, or taking a rest. Sofas and benches play an essential role in satisfying users' purposes according to the observed traffic patterns in Figures 5 and 6. Based on this observation result, we infer that the users' behaviors in the IC and U-Lounge are distinctly different. The structural differences and properties of the facilities of the IC and U-Lounge lead to different usage patterns and user behavior.

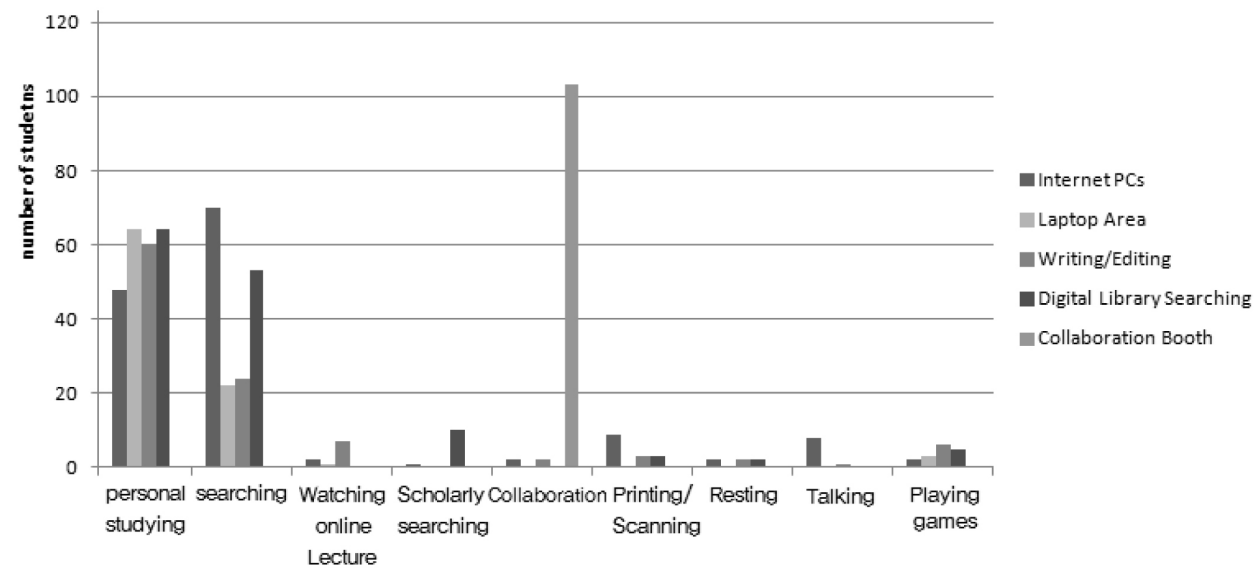

〈Figure 7〉 Frequency of Activities in the IC

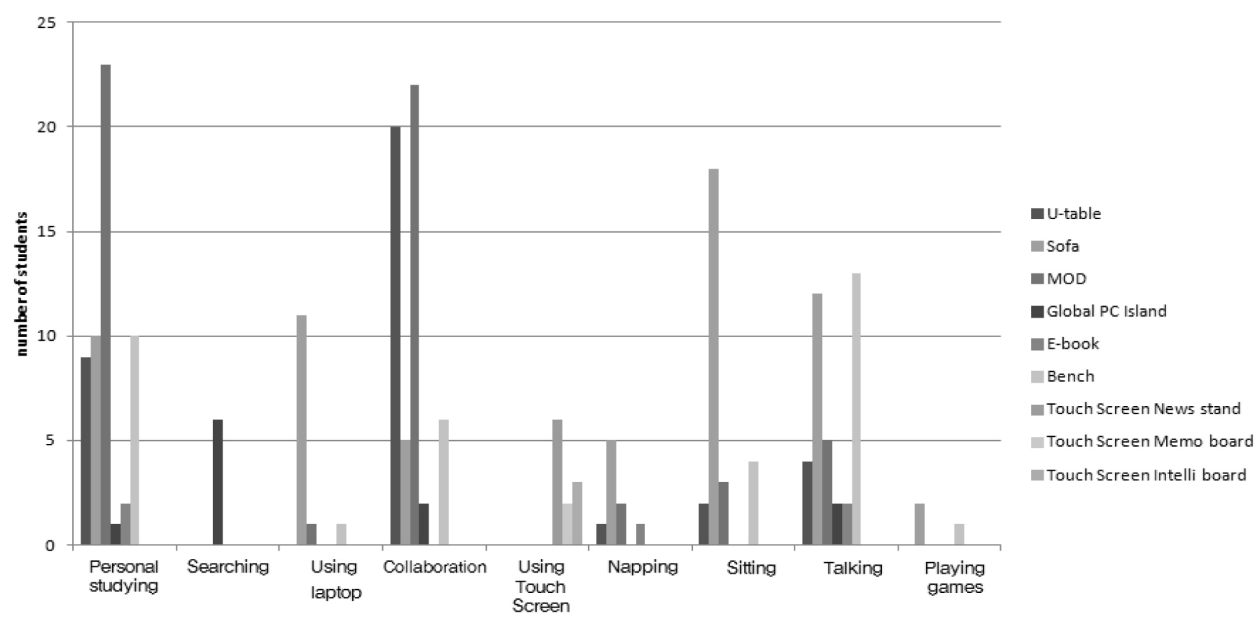

〈Figure 8〉 Frequency of Activities in the U-Lounge 


\section{Interview Data Analysis and Findings}

Analyzing the interview data focused on user perceptions toward the library space. To determine the relationship between frequency of visits and change of recognition, we asked interviewees how often they use the IC or U-Lounge during a typical week and for what purpose. We asked general questions rather than specific to get a better idea of respondents' behaviors, thoughts, and feelings.

The recorded interview data were fully analyzed without any sampling. The semi-structured responses were categorized based on either the interview guideline category or additional categories especially for follow-up responses. These categories play a role of codes in a coding process.

Overall, out of 32 observed users, about $50 \%$ answered that they utilize these facilities more than once a week. Interestingly, many undergraduates visit the IC or U-Lounge frequently, while graduates visit rarely.

Fifteen $(68 \%)$ of a total of 22 undergraduate interviewees answered that they visit the library more than once a week and the remaining $22 \%$ drop by less than once a week. On the other hand, only two $(17 \%)$ of the 12 graduate interviewees visit the library more than a week and $10(83 \%)$ go to the library less than once a week.

Most undergraduates visit the IC or U-Lounge to do homework in the computing seats, do group work in collaborative booths, and sometimes take a rest. However, all 12 graduates indicated that they rarely use the IC or U-Lounge for group study. Most graduates focus on individual study rather than group study. If they do visit, they have a specific purpose and leave after a short stay. This pattern is closely related to their perceptions of the library. Callinan (2005) explained that undergraduate students primarily use the library as a place to study and carry out a variety of activities within the library. Graduates, in contrast, rely heavily on online resources, because they do not need to make a physical visit to the library (George, Bright, Hurlbert, Linke, St. Clair, \& Stein, 2006).

Perceptions of the IC and U-Lounge are quite different between undergraduates and graduates with respect to the advantages and improvements. Many undergraduates think the IC and U-Lounge have the advantage of being in the center of the campus, equipped with modern facilities and interior design, in a free atmosphere, and offering many resting spaces. One of the most interesting comments was that they see the library with the IC and U-Lounge as a place for various activities rather than a place for study. Some interviewees said this space makes them feel a sense of belonging to their university. Even though they are rare visitors, many graduates expressed positive opinions about the spaces, which have allowed them to rest or socialize in an academic environment. However, for some graduates, the environment that allows users to make noise did not fit their purposes.

Concerning the issue of improvements, many undergraduates wanted to have enough computer facilities and collaborative rooms to use whenever they want. As such, they supported upgrading the facilities. 
Graduates expressed that the library needed to establish a noise regulation. Some interviewees provided useful suggestions for managing the IC, such as moving the kiosks near the seating areas and regulating the users who do not use the seats after registering.

Regarding perceptual changes, $71.8 \%$ of the interviewees (see Table 1) changed their impression of the library after experiencing the IC and U-Lounge. Of these, $87 \%$ said that their impression was changed toward a positive attitude, as the IC and U-Lounge had a good influence on the way they thought about or used the library. Some interviewees mentioned that they became familiar with the library and visited it more often.

Based on the interview data analysis, the present study found a relationship between the change of recognition and frequency of users' visits to the IC and U-Lounge. Out of 18 visitors who visited more than once a week, $15(88.2 \%)$ had a positive perception of the library. They mentioned that they visited the library more often because of the atmosphere and facilities, such as computers, resting places, and group study rooms. This means that the more often the users visited the library, the more positive they became.

There was also difference between undergraduate students and graduate students in their frequency of visits and perceptions of change. Undergraduate students tended to visit frequently, and their attitudes tended to turn more positive. Overall, 17 of 20 undergraduate users replied that they changed their perception of the library, and 15 took affirmative stands. The purpose of their visits included spending time between classes, meeting friends, and doing individual homework or group studies. They enumerated the strengths of the IC and U-lounge as providing a free conversation space, easily accessible, diverse facilities in one spot, resting places, and the wide-open space. The undergraduate interviewees showed that many considered the library as quite different from the traditional concept. Many undergraduates regarded the library not only as a place for borrowing books but also as a place for engaging in various activities. Some interviewees seemed to think the library is a complex cultural space.

〈Table 1$\rangle$ Change of recognition toward libraries by frequency of visits to the IC and U-Lounge

\begin{tabular}{c|c|c|c|c|c}
\hline $\begin{array}{c}\text { Frequency of } \\
\text { Visits }\end{array}$ & $\begin{array}{c}\text { Changes of } \\
\text { Recognition }\end{array}$ & $\begin{array}{c}\text { \# of Under-graduate } \\
\text { Students }\end{array}$ & $\begin{array}{c}\text { \# of Graduate } \\
\text { Students }\end{array}$ & Total & Percent \\
\hline \multirow{3}{*}{$\begin{array}{c}\text { More than } \\
\text { once a week }\end{array}$} & Toward Positive & 13 & 2 & 15 & $46.9 \%$ \\
\cline { 2 - 6 } & Toward Negative & 1 & 0 & 1 & $3.1 \%$ \\
\cline { 2 - 6 } & Unchanged & 1 & 1 & 2 & $6.3 \%$ \\
\hline \multirow{2}{*}{$\begin{array}{c}\text { Less than } \\
\text { once a week }\end{array}$} & Toward Positive & 3 & 2 & 5 & $15.6 \%$ \\
\cline { 2 - 6 } & Toward Negative & 0 & 2 & 2 & $6.3 \%$ \\
\cline { 2 - 6 } & Unchanged & 2 & 12 & 32 & $100 \%$ \\
\hline \multicolumn{2}{c}{ Total } & 20 & & & $21.9 \%$ \\
\hline
\end{tabular}


Graduate students, in contrast, showed a different tendency. In-person interviews of graduates showed that the IC and U-Lounge changed the attitudes of about half of the graduate interviewees toward the library. As Table 1 indicates, 4 of the 12 graduates indicated positive perceptions of the library. Two frequent users of the IC and U-Lounge changed their attitudes positively. Two rare visitors had a negative perception of the library, because they thought that the new space was too fancy and it just tries to show off its facilities. The graduate students had fewer reasons to come to the IC and U-Lounge, because they usually have an allocated laboratory with personal computers and their works are often based on individual tasks rather than group projects. This result may be somewhat different from other countries, because most Master's degree and doctoral programs in Korea require an academic thesis. This may require students to invest their time in individual study.

The above-mentioned factors, however, may explain limited aspects of the attitudinal changes. Some interviewees who were rare visitors perceived the library positively. In addition, a few people answered that their perception did not change or changed to a negative perception, even though they visited the IC and U-lounge frequently. After analyzing the interview data for these exceptional cases, we concluded that another factor causes users' to change their perceptions. We noticed that the changes in attitudes toward the library were closely related with whether people use the IC and U-Lounge as a knowledge commons. As mentioned, we have identified that the IC is a well-suited environment for creating knowledge because "the creation of new knowledge is a socially negotiated process" (Fister, 2004, p. 2). Users who engage in group studies or any collaborative activities in this space were considered to use the provided space as a knowledge commons. Collaboration is an essential element for mutual understanding of a certain context that eventually leads to new knowledge creation. The socially negotiated processes mean such mutual understanding of a context.

$\langle$ Table 2〉 Change of recognition toward the library by pattern of use

\begin{tabular}{|c|c|c|c|}
\hline & Pattern of Use & Change of Recognition & \# of Students \\
\hline \multirow{6}{*}{$\begin{array}{l}\text { Undergraduate } \\
\text { Students }\end{array}$} & \multirow{3}{*}{$\begin{array}{l}\text { Used as a Knowledge } \\
\text { Commons }\end{array}$} & Toward Positive & 14 \\
\hline & & Toward Negative & 1 \\
\hline & & Unchanged & 0 \\
\hline & \multirow{3}{*}{$\begin{array}{l}\text { Not used as Knowledge } \\
\text { Commons }\end{array}$} & Toward Positive & 2 \\
\hline & & Toward Negative & 0 \\
\hline & & Not changed & 3 \\
\hline \multirow{6}{*}{$\begin{array}{l}\text { Graduate } \\
\text { Students }\end{array}$} & \multirow{3}{*}{$\begin{array}{l}\text { Used as a Knowledge } \\
\text { Commons }\end{array}$} & Toward Positive & 2 \\
\hline & & Toward Negative & 0 \\
\hline & & Not changed & 0 \\
\hline & \multirow{3}{*}{$\begin{array}{l}\text { Not used as a Knowledge } \\
\text { Commons }\end{array}$} & Toward Positive & 2 \\
\hline & & Toward Negative & 2 \\
\hline & & Not changed & 6 \\
\hline
\end{tabular}




\subsection{Change to Positive Attitude}

As Table 2 illustrates, users tended to have positive attitudes when they perceived the IC and U-lounge as a knowledge commons. Overall, 16 of the 17 interviewees who used the IC and U-lounge as knowledge commons answered that their attitudes changed to positive and only one of them said that his attitude changed to negative.

Considering all 20 undergraduate students, 15 replied they use the space as a knowledge commons. Fourteen (95\%) responded they view library positively, while one user had the opposite view. In case of graduate students, only 2 of the 12 interviewees answered that they used the common space as a knowledge commons and their attitudes toward the library changed to positive.

Interviewees who changed their attitudes to positive expressed that the features of the IC and U-lounge reflected the library's advancement according to the digital age, and that the library offered a place to interchange ideas freely. As such, it becomes a symbol of a library, which has the potential to be used for various purposes as community space. One respondent who left a negative comment said that the IC and U-Lounge cause repulsion of its demonstration effect.

\subsection{Change to Negative Attitude}

Conversely, most users who rarely use the IC and U-Lounge as a knowledge commons stated that their attitude toward the library did not change or changed to negative. Fifteen of all the interviewees responded that they do not use the space as a knowledge commons. Nine of these 15 answered that this common space did not affect their perceptions, and two said their attitudes toward the library changed to negative.

Of five undergraduate students, three replied that their attitudes did not change after experiencing the IC and U-Lounge. In the case of graduates, 10 of the 12 answered they did not use these spaces as a knowledge commons. Six of the respondents had no change in attitudes and two showed a negative change. People who mentioned the non-knowledge-commons use gave several reasons for their unchanged recognition. They did not have enough experience with the facilities to affect a change in attitude and believed that those places had nothing to do with their needs. They noticed only that the spaces became larger and did not have specific opinions of them because the IC and U-Lounge did not meet their purpose to visit the library. Negative comments concerned the wasteful use of space and the lack of space for individual study.

Some exceptions in student responses also emerged. Some users replied their attitude changed positively even though they did not consider the IC and U-Lounge as a knowledge commons. Two of 5 undergraduates did not use the IC and U-Lounge as a knowledge commons but had a positive change in attitudes. Two of 10 graduates also stated that their attitude changed to positive, regardless of their pattern of use. They liked the facilities because they provided enough resting spaces. 


\section{Discussion and Conclusion}

The present study provides information on attitudes toward the IC and U-Lounge and the way they change perceptions of the entire library. We noticed that users engaged in various activities, including group study, individual study, and resting, depending on their purposes, traffic patterns, and observation data. Our findings indicate that differences between undergraduate students and graduate students exist. Based on the analyses of the interviews, we found that not only the frequency of visits but also the purpose of use greatly influenced users' perceptions of the library. Many users who recognize the library as a knowledge commons changed their perceptions of the library from a traditional space for borrowing books and quiet studying into a knowledge-sharing space. The role of the library has been influenced largely by the advent of the digital and information age. As society develops, what matters is not acquiring information, but how to use the acquired information more effectively. This notion is supported by the perception of the space as a knowledge commons in the present study. Therefore, even the users who rarely visit the library could change their attitude toward positive if they recognize the fact that libraries provide spaces for sharing.

It turned out that more students engage in individual work in the IC compared to the U-Lounge. This could be explained by the private seats assigned by kiosk. The present study also found that the facilities for group study are inadequate to meet the needs of users. To satisfy demands, the library needs to expand and improve collaborative workspaces to guarantee interactive communication and design spaces. The library should be dedicated to developing the areas as a knowledge commons as a whole.

The result that graduate students rarely visit the IC and U-Lounge may indicate that the library provides insufficient research support. It could be said that the library should meet the extra requirements of their graduate students at this point. On the other hand, facilities for graduates, including carrels, exist at libraries in North America and Europe (Bordonaro, 2013; Gibbons, 2013).

This study contributes to the stream of previous relevant studies by suggesting a new value for library space. While most previous studies on library service satisfaction have focused on the intangible aspects in most cases, the present study proposes that the so-called, "spatial satisfaction," which differs from traditional service satisfaction in the sense of physical environments plays a significant role in attracting users. According to the present study, spatial satisfaction could influence the initial visit and revisits to a library. This concept of spatial satisfaction needs further studies in more general settings to draw any further conclusions.

The practical implications from these findings include that the IC and U-Lounge should perform its role as a buffer in the process of transforming the library from a traditional to a new concept. As shown in the present study, the role of the IC and U-Lounge is essential for promoting change in users' perceptions. We suggest that library planners design the common space in a highly accessible area through which users 
walk, and consider the different usage patterns among undergraduate students and graduate students. A better understanding of desirable roles for common spaces and the relationship between the IC and users' perceptions can help promote the benefits of library services as a whole, which would eventually increase user traffics to library as well as to IC. Traditionally, li- braries have been considered as providing information (e.g., maximum-liberal reference model) and education (e.g., minimum-conservative reference model). As this study discovered, library space can also be a valuable service. The spatial satisfaction of library users would be one of main factors that make them to revisit, reuse, and rethink library services.

\section{References}

Bae, K.-J. (2010). The analysis of the differences of information needs and usages among academic users in the field of science and technology. Journal of Korean Society for Library and Information Science, 44(2), 157-176. http://dx.doi.org/10.4275/KSLIS.2010.44.2.157

Barret, A. (2005). The Information-seeking habits of graduate student researchers in the humanities. Journal of Academic Librarianship, 31(4), 324-331.

Beagle, D. (1999). Conceptualizing an information commons. Journal of Academic Librarianship, 25(2), 82-89. http://dx.doi.org/10.1016/S0099-1333(99)80003-2

Beagle, D. (2010). Emergent information commons: Philosophy, models, and 21st century learning paradigms. Journal of Library Administration, 50(1), 7-26. http://dx.doi.org/10.1080/01930820903422347

Beatty, S. (2010). Information commons, University of Calgary: Providing service through collaboration and integration. Journal of Library Administration, 50(2), 145-159.

http://dx.doi.org/10.1080/01930820903455008

Bennett, S. (2003). Libraries designed for learning. Coucile on the Library and Information Resources. Washington D.C.

Bordonaro, K. (2013). Internationalization and the North American University Library. Scarecrow Press.

Bryant, J., Matthews. G., \& Walton, G. (2009). Academic libraries and social and learning space: A case study of Loughborough University Library, UK. Journal of Librarianship and Information Science, 41(1), 7-18. http://dx.doi.org/10.1177/0961000608099895

Callinan., J. E. (2005). Information-seeking behaviour of undergraduate biology students: A comparative analysis of first year and final year students in University College Dublin. Library Review, 54(2), 86-99. http://dx.doi.org/10.1108/00242530510583039 
Campbell, D. E., \& Shlechter, T. M. (1979). Library design influences on user behavior and satisfaction. Library Quarterly, 49(1), 26-41.

Cullen, R. (2001). Perspectives on user satisfaction surveys. Library Trends, 49(2), 662-686.

Fister, B. (2004). Common ground: Libraries and learning. Library Issues: Briefings for Faculty and Administrators, 25(1). Retrieved from http://libraryissues.com/sub/LI250001.asp

George, C., Bright, A., Hurlbert, T., Linke, E.C., St. Clair, G. \& Stein, J. (2006). Scholarly use of information: Graduate students' information seeking behavior. Information Research, 11(4), paper 272. Retrieved from http://nformationR.net/ir/11-4/paper272.html

Gibbons, S. (2013). Techniques to understand the changing needs of library users. IFLA Journal, 39(2), 162-167. http://dx.doi.org/10.1177/0340035212472846

Given, L., \& Leckie, G. (2003). "Sweeping" the library: Mapping the social activity space of the public library. Library \& Information Science Research, 25(4), 365-385. http://dx.doi.org/10.1016/S0740-8188(03)00049-5

Halbert, M. (2010). The information commons: A platform for innovation. Journal of Library Administration, 50(1), 67-74. http://dx.doi.org/10.1080/01930820903422107

Hartmann. E. (2001). Understanding of information literacy: The perception of first year undergraduate students at the University of Ballarnt. Austrailian Academic and Research Libraries, 32(2), 110-122. http://dx.doi.org/10.1080/00048623.2001.10755150

Hiller, S. (2002). How differenct are they? A comparison by academic area of library use, priorities and information needs at the University of Washington. Issues in Science and Technology Librarianship, 33, article 1. Retrieved from http://www.istl.org/02-winter/article1.html [cited 2012.6.25]

Lippincott, J. K., \& Oblinger, D. G. Ed. (2006). Learning spaces. Washington DC: Educase.

Lippincoat, J. K. (2010). Information commons: Meeting millennials' needs. Journal of Library Administration, 50(1), 27-37. http://dx.doi.org/10.1080/01930820903422156

Longhurst, R. (2003). Semi-structured interviews and focus groups. In: N. Clifford \& G. Valentine (Eds), Key methods in geography, pp. 117-132 (London: Sage).

MacWhinnie, L. A. (2003). The information commons: The academic library of the future. portal: Libraries and the Academy, 3(2), 241-257. http://dx.doi.org/10.1353/pla.2003.0040

Malenfant, C. (2006). The information commons as a collaborative workspace. Reference Services Review, 34(2), 279-286. http://dx.doi.org/10.1108/00907320610669506

Mandel, L. (2010). Toward an understanding of library patron wayfinding: Observing patrons' entry routes in a public library. Library and Information Science Research, 32(2), 116-130. http://dx.doi.org/10.1016/j.lisr.2009.12.004 
110 정보관리학회지 제 30 권 제 4 호 2013

Seal, R. (2005). The information commons: New pathways to digital resources and knowledge management. In Proceedings of the 3rd China-U.S. Library Conference (Shanghia, China), 67-75.

Sommer, B., \& Sommer, R. (1997) A practical guide to behavioral research: Tools and techniques (4th ed). New York: Oxford University Press.

Tongco, M. D. C. (2007). Purposive sampling as a tool for informant selection. Ethnobotany Research \& Applications, 5, 147-158. Retrieved from www.ethnobotanyjournal.org/vol5/i1547-3465-05-147.pdf Whitchurch, M. J. (2010). Planning an information commons. Journal of Library Administration, 50(1), 39-50. http://dx.doi.org/10.1080/01930820903422370 